\title{
Magnesium Alleviates Adverse Effects of Lead on Growth, Photosynthesis, and Ultrastructural Alterations of Torreya grandis Seedlings
}

\author{
Jie Shen ${ }^{1 \dagger}$, Lili Song ${ }^{1 \dagger}$, Karin Müller ${ }^{2}$, Yuanyuan Hu${ }^{1}$, Yang Song ${ }^{1}$, Weiwu Yu ${ }^{1}$, \\ Hailong Wang ${ }^{3}$ and Jiasheng $\mathrm{Wu}^{1 *}$
}

\begin{abstract}
'The Nurturing Station for the State Key Laboratory of Subtropical Silviculture, Zhejiang A \& F University, Zhejiang, China, ${ }^{2}$ New Zealand Institute for Plant and Food Research Limited, Ruakura Research Centre, Hamilton, New Zealand, ${ }^{3}$ Key Laboratory of Soil Contamination Bioremediation of Zhejiang Province, Zhejiang A \& F University, Zhejiang, China
\end{abstract}

\section{OPEN ACCESS}

Edited by: Jian-Guo Huang,

University of Chinese Academy of Sciences, China

Reviewed by: Anitha Kunhikrishnan, National Institute of Agricultural

Science, South Korea

Lei Chen,

Hokkaido University, Japan

*Correspondence:

Jiasheng Wu

wujs@zafu.edu.cn

tThese authors have contributed equally to this work.

Specialty section:

This article was submitted to

Functional Plant Ecology,

a section of the journal

Frontiers in Plant Science

Received: 30 September 2016 Accepted: 18 November 2016 Published: 30 November 2016

Citation:

Shen J, Song L, Müller $K, H u Y$, Song $Y, Y u W$, Wang $H$ and $W u J$ (2016) Magnesium Alleviates Adverse Effects of Lead on Growth, Photosynthesis, and Ultrastructural Alterations of Torreya grandis Seedlings. Front. Plant Sci. 7:1819. doi: 10.3389/fpls.2016.01819
Magnesium $\left(\mathrm{Mg}^{2+}\right)$ has been shown to reduce the physiological and biochemical stress in plants caused by heavy metals. To date our understanding of how $\mathrm{Mg}^{2+}$ ameliorates the adverse effects of heavy metals in plants is scarce. The potential effect of $\mathrm{Mg}^{2+}$ on lead $\left(\mathrm{Pb}^{2+}\right)$ toxicity in plants has not yet been studied. This study was designed to clarify the mechanism of $\mathrm{Mg}^{2+}$-induced alleviation of lead $\left(\mathrm{Pb}^{2+}\right)$ toxicity. Torreya grandis (T. grandis) seedlings were grown in substrate contaminated with 0 , 700 and $1400 \mathrm{mg} \mathrm{Pb}^{2+}$ per $\mathrm{kg}^{-1}$ and with or without the addition of $1040 \mathrm{mg}$ $\mathrm{kg}^{-1} \mathrm{Mg}^{2+}$. Growth parameters, concentrations of $\mathrm{Pb}^{2+}$ and $\mathrm{Mg}^{2+}$ in the plants' shoots and roots, photosynthetic pigment, gas exchange parameters, the maximum quantum efficiency (Fv/Fm), root oxidative activity, ultrastructure of chloroplasts and root growth were determined to analyze the effect of different $\mathrm{Pb}^{2+}$ concentrations on the seedlings as well as the potential ameliorating effect of $\mathrm{Mg}^{2+}$ on the $\mathrm{Pb}^{2+}$ induced toxicity. All measurements were tested by a one-way ANOVA for the effects of treatments. The growth of $T$. grandis seedlings cultivated in soils treated with $1400 \mathrm{mg}$ $\mathrm{kg}^{-1} \mathrm{~Pb}^{2+}$ was significantly reduced compared with that of plants cultivated in soils treated with 0 or $700 \mathrm{mg} \mathrm{kg}^{-1} \mathrm{~Pb}^{2+}$. The addition of $1040 \mathrm{mg} \mathrm{kg}^{-1} \mathrm{Mg}^{2+}$ improved the growth of the $\mathrm{Pb}^{2+}$-stressed seedlings, which was accompanied by increased chlorophyll content, the net photosynthetic rate and Fv/Fm, and enhanced chloroplasts development. In addition, the application of $\mathrm{Mg}^{2+}$ induced plants to accumulate five times higher concentrations of $\mathrm{Pb}^{2+}$ in the roots and to absorb and translocate four times higher concentrations of $\mathrm{Mg}^{2+}$ to the shoots than those without $\mathrm{Mg}^{2+}$ application. Furthermore, $\mathrm{Mg}^{2+}$ addition increased root growth and oxidative activity, and protected the root ultrastructure. To the best of our knowledge, our study is the first report on the mechanism of $\mathrm{Mg}^{2+}$-induced alleviation of $\mathrm{Pb}^{2+}$ toxicity. The generated results may have important implications for understanding the physiological interactions between heavy metals and plants, and for successful management of $T$. grandis plantations grown on soils contaminated with $\mathrm{Pb}^{2+}$.

Keywords: Torreya grandis, lead toxicity, magnesium, heavy metal phytotoxicity, phytoremediation 


\section{INTRODUCTION}

Heavy metal pollution has become a global environmental threat (Krabbenhoft and Sunderland, 2013; Chen et al., 2015). Among metal contaminants, lead $\left(\mathrm{Pb}^{2+}\right)$ is a major concern because of its extensive distribution in the environment and the substantial environmental and human health problems it can cause. Major sources of $\mathrm{Pb}^{2+}$ pollution include mining and smelting activities as well as $\mathrm{Pb}^{2+}$-containing paints, gasoline, explosives, sewage sludge and fertilizers (Sharma and Dubey, 2005; Buekers et al., 2009). When plants are exposed to $\mathrm{Pb}^{2+}$, even at micromolar levels, adverse effects can occur on plant growth (Hadi et al., 2010), root elongation (Liu et al., 2000), seed germination (Lamhamdi et al., 2011), seedling development (Kaur et al., 2015), chlorophyll production (Rashid and Popovic, 1990), chloroplast lamellar organization ( $\mathrm{Hu}$ et al., 2007), and antioxidant enzymes system (Gupta et al., 2009, 2010). However, the toxicological response to $\mathrm{Pb}^{2+}$ varies depending on the plant species and tissues analyzed (Pourrut et al., 2011). Huang and Cunningham (1996) showed significant differences in the uptake and translocation of $\mathrm{Pb}^{2+}$ among Triticum aestivum, Thlaspi rotundifolium, and Thlaspi caerulescens. Mimosa caesalpiniaefolia was more tolerant to high $\mathrm{Pb}^{2+}$ concentrations in soil than Erythrina speciosa and Schizolobium parahyba (de Souza et al., 2012). Huang and Cunningham (1996) found that some dicot species can accumulate significantly higher concentrations of $\mathrm{Pb}^{2+}$ in the roots than some monocot species.

Heavy metals could be taken up by cation transporters such as members of the ZIP (Zn-regulated transporter/Feregulated transporter-like protein) and natural resistanceassociated macrophage protein families (Eide et al., 1996; Korshunova et al., 1999; Guerinot, 2000; Thomine et al., 2000). These bivalent cation transporters are also important uptake systems for essential elements. Therefore, nutrients such as magnesium $\left(\mathrm{Mg}^{2+}\right)$ are considered to contribute to plants' tolerance to heavy metal exposure owing to their chemical similarity as well as sharing common transporters with heavy metals (Guerinot, 2000; Pittman, 2005). Over the last decade, studies have revealed the ability of $\mathrm{Mg}^{2+}$ to mitigate heavy metal toxicity caused by aluminum $\left(\mathrm{Al}^{3+}\right)$ and cadmium $\left(\mathrm{Cd}^{2+}\right)$ (Kashem and Kawai, 2007; Bose et al., 2011). Kashem and Kawai (2007) reported that adding $\mathrm{Mg}^{2+}$ to nutrient solutions reduced Cd concentrations in plants and enhanced the growth of plants suffering from Cd toxicity. Hermans et al. (2011) indicated that the protective effect of $\mathrm{Mg}^{2+}$ against $\mathrm{Cd}$ toxicity may be at least partly attributed to the protection of the photosynthetic apparatus. However, only few studies have investigated the effect of $\mathrm{Mg}^{2+}$ on $\mathrm{Pb}^{2+}$ toxicity. Therefore, we explored the effect of $\mathrm{Mg}^{2+}$ on $\mathrm{Pb}^{2+}$ toxicity and the possible mechanism of $\mathrm{Mg}^{2+}$. induced alleviation of $\mathrm{Pb}^{2+}$ toxicity using a local species Torreya grandis (T. grandis).

Torreya grandis is a gymnosperm tree species belonging to the Taxaceae family, mainly grown in eastern China with significant economic value because of its valuable drupe-like fruits with medicinal effects from its anthelmintic, antitussive, carminative, laxative, antifungal, antibacterial, and antitumor properties (Huang et al., 2001). As the demand for the fruit increased, the acreage of $T$. grandis has rapidly expanded, and the management intensity has increased with higher inputs of fertilizers and pesticides, such as lead arsenate. In addition, soils near highways, which are usually polluted by exhaust emissions, have also been used for growing $T$. grandis. Therefore, T. grandis is likely to face with $\mathrm{Pb}^{2+}$ stress. It remains unclear whether T. grandis can be tolerant to high level of $\mathrm{Pb}^{2+}$ stress. Thus, in this study, we performed a pot experiment to test the following hypotheses: (1) High level $\mathrm{Pb}^{2+}$ stress inhibits the growth of T. grandis seedlings; (2) $\mathrm{Mg}^{2+}$ can effectively ameliorate the negative effects of lead stress on the growth of $T$. grandis seedlings. The information obtained in this study is valuable for the propagation and cultivation of $T$. grandis under $\mathrm{Pb}^{2+}$ stress conditions.

\section{MATERIALS AND METHODS}

\section{Plant Material and Growth Conditions During All Experiments}

All experiments were conducted on the Zhejiang A \& F University campus, Lin'an City, Zhejiang province $\left(330^{\circ} 23^{\prime} \mathrm{N}\right.$, $\left.119^{\circ} 72^{\prime} \mathrm{E}\right)$, China. Two-year-old uniform and healthy T. grandis seedlings (mean ground diameter $5 \pm 0.5 \mathrm{~mm}$ and seedling height $35 \pm 2 \mathrm{~cm})$ were transplanted into plastic pots $(16.5 \mathrm{~cm}$ inner diameter, $18 \mathrm{~cm}$ height, with holes in the bottom, one seedling per pot) filled with $2.5 \mathrm{~kg}$ of sterilized substrate mixture of perlite and quartz sand $(1: 1, \mathrm{v} / \mathrm{v})$. All pots were irrigated with $200 \mathrm{ml}$ of Hoagland's nutrient solution (3.0 $\mathrm{mM} \mathrm{KNO}_{3}$, $2.5 \mathrm{mM} \mathrm{Ca}\left(\mathrm{NO}_{3}\right)_{2}, 1.0 \mathrm{mM} \mathrm{MgSO}{ }_{4} \cdot 7 \mathrm{H}_{2} \mathrm{O}, 1.2 \mu \mathrm{M}$ FeEDTA, $4.0 \mu \mathrm{M} \mathrm{MnCl} 2,22.0 \mu \mathrm{M} \mathrm{H}_{3} \mathrm{BO}_{3}, 0.4 \mu \mathrm{M} \mathrm{ZnSO}, 0.05 \mu \mathrm{M}$

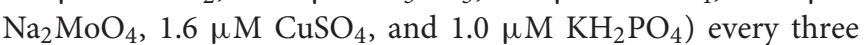
days and maintained at $75 \%$ field capacity of the growth substrate to keep the plants well watered. Day and night temperature was kept between 18.0 and $32.0^{\circ} \mathrm{C}$ and the relative humidity ranged between 50 and $80 \%$. The light intensity in the greenhouse was monitored daily with an external quantum sensor attached to LI-6400 (Li-COR, Lincoln, NE, USA) and kept within the range of 500-800 $\mu \mathrm{mol} \mathrm{m} \mathrm{m}^{-2} \mathrm{~s}^{-1}$ photosynthetically active radiation (PAR) above the plants.

\section{First Experiment: Exposure of Seedlings to $\mathrm{Pb}^{2+}$}

The first experiment to determine the lead concentration that adversely affected $T$. grandis seedlings was carried out between 1 May and 31 June 2014. One month after transplantation of the seedlings, the height and ground diameter of each seedling were measured as reference values. A completely randomized design with three replications per treatment and five plants per replication was chosen. Total of 45 seedlings were exposed to $\mathrm{Pb}^{2+}$ supplied as $\mathrm{Pb}\left(\mathrm{NO}_{3}\right)_{2}$ at concentrations of 0 (control), 700 and $1400 \mathrm{mg} \mathrm{Pb}^{2+} \mathrm{kg}^{-1}$ growth substrate. These concentrations were selected based on a report by Huang et al. (2006), who found that $\mathrm{Pb}^{2+}$-concentrations in soil exceeding $1000 \mathrm{mg} \mathrm{kg}^{-1}$ affected the growth of Pinus rigida. After 60 days, the height and ground diameters of the seedlings were recorded. 


\section{Second Experiment: Exposure of Seedlings to $\mathrm{Pb}^{2+}$ and $\mathrm{Mg}^{2+}$}

The above experiment showed that $1400 \mathrm{mg} \mathrm{kg}^{-1} \mathrm{~Pb}^{2+}$ caused $\mathrm{Pb}^{2+}$ toxicity in $T$. grandis seedlings. Hence, further studies on the effect of $\mathrm{Mg}^{2+}$ on $\mathrm{Pb}^{2+}$ toxicity were restricted to the control and the $1400 \mathrm{mg} \mathrm{kg}^{-1} \mathrm{~Pb}^{2+}$ treatments. This second experiment was conducted during 1 May to 31 June 2015. Magnesium (with the irrigation water) was supplied as $\mathrm{MgCl}_{2}$ at $1040 \mathrm{mg} \mathrm{kg}^{-1}$. In total, the following four treatments (total of 60 seedlings) were established: $\mathrm{T} 1$ (control without $\mathrm{Mg}^{2+}$ addition); T2 (control with $1040 \mathrm{mg} \mathrm{kg}^{-1} \mathrm{Mg}^{2+}$ ); T3 (1400 $\mathrm{mg} \mathrm{kg}^{-1} \mathrm{~Pb}^{2+}$ without $\left.1040 \mathrm{mg} \mathrm{kg}^{-1} \mathrm{Mg}^{2+}\right)$ and T4 (1400 mg kg${ }^{-1} \mathrm{~Pb}^{2+}$ with $1040 \mathrm{mg} \mathrm{kg}^{-1} \mathrm{Mg}^{2+}$ ). A completely randomized design with three replications per treatment and five plants per replication was set up.

\section{Plant Harvest}

After 60 days of the second experiment, the third and fourth leaves from the plant top, which had been completely developed when $\mathrm{Pb}^{2+}$ treatment started, were collected from all plants, cleaned with tissue paper to remove any surface contamination, immediately frozen in liquid nitrogen and stored at $-70^{\circ} \mathrm{C}$. Plant growth, concentrations of $\mathrm{Pb}^{2+}$ and $\mathrm{Mg}^{2+}$ in shoots and roots, chlorophyll concentration, root oxidative activity, photosynthesis and ultrastructure of chloroplasts and roots were determined for all samples.

\section{Growth and Morphology Analysis}

After 60 days of the two experiments, all seedlings were harvested and separated into shoots and roots for growth and morphology analyses. Shoot biomass and total biomass were measured after drying of the shoots and roots at $80^{\circ} \mathrm{C}$ for 4 days. Seedling height was defined as the height of the plant from the top of the growth medium to the tip of the uppermost shoot.

\section{Determination of $\mathrm{Pb}^{2+}$ and $\mathrm{Mg}^{2+}$ Concentrations in Plant Shoots and Roots}

To determine the concentrations of $\mathrm{Pb}^{2+}$ and $\mathrm{Mg}^{2+}$ in the shoots and roots, the dried plant materials were grounded with a stainless steel mill and passed through a $0.25 \mathrm{~mm}$ sieve for analysis of $\mathrm{Pb}^{2+}$ and $\mathrm{Mg}^{2+}$. An aliquot of $0.1 \mathrm{~g}$ of the dried plant materials of each treatment was digested with $\mathrm{HNO}_{3}-$ $\mathrm{HClO}_{4}(4: 1, \mathrm{v} / \mathrm{v})$, and the digest was diluted with deionized water (DW) to a final volume of $50 \mathrm{~mL}$. Concentrations of $\mathrm{Pb}^{2+}$ and $\mathrm{Mg}^{2+}$ in the filtrates were analyzed by flame atomic absorption spectroscopy (Perkin Elmer Analyser 300, England). The $\mathrm{Pb}^{2+}$ and $\mathrm{Mg}^{2+}$ concentrations in the entire plant were calculated following Zhang et al. (2011) and expressed in $\mathrm{mg} \mathrm{kg}^{-1} \mathrm{DW}$ and $\mathrm{mg} \mathrm{g}^{-1} \mathrm{DW}$, respectively.

\section{Pigment Concentration in Leaves}

Approximately $0.1 \mathrm{~g}$ of finely cut and well-mixed fresh plant sample, which was taken from healthy and fully developed leaves at the same position in each treatment, was repeatedly extracted with $8 \mathrm{~mL}$ of $95 \%$ ethanol (100\%, Sinopharm Chemical
Reagent Company, Shanghai, China). Pigment was extracted at $4^{\circ} \mathrm{C}$ for $24 \mathrm{~h}$ in darkness and shaken three or four times until the leaf samples blanched (no green color in the leaf tissue). The absorbance was measured with a Shimadzu UV-2550 spectrophotometer (Kyoto, Japan) at 664, 649, and $470 \mathrm{~nm}$ after centrifugation of the mixture. The chlorophyll a (Chla), chlorophyll b (Chlb), total chlorophyll $(\mathrm{Chl}(\mathrm{a}+\mathrm{b}))$, and carotenoid (Car) contents were calculated using the following formulas (Lichtenthaler, 1987). Results are expressed in $\mathrm{mg} \mathrm{g}^{-1}$ fresh weight (FW).

$$
\begin{gathered}
C_{a}\left(g L^{-1}\right)=13.36 A_{664}-5.19 A_{649} \\
C_{b}\left(g L^{-1}\right)=27.43 A_{649}-5.10 A_{664} \\
C_{a+b}\left(g L^{-1}\right)=5.24 A_{664}-22.24 A_{649} \\
C x+c\left(g L^{-1}\right)=\frac{1000 A_{470}-2.13 C_{a}-97.64 C_{b}}{209}
\end{gathered}
$$

Where, $\mathrm{C}_{a}, \mathrm{C}_{b}, \mathrm{C}_{a+b}$, and $\mathrm{C}_{x+c}$ were the concentrations of Chla, Chlb, Chl (a+b), and Car, respectively. $A_{664}, A_{649}$, and $A_{470}$ were the absorbances of pigment extract solution at 664,649 , and $470 \mathrm{~nm}$ wavelengths, respectively.

\section{Photosynthetic Parameters and the Maximum Quantum Efficiency of Psii Photochemistry (Fv/Fm)}

The youngest healthy and fully developed leaves randomly selected from the first branch were chosen for gas exchange measurements. Field gas exchange measurements were conducted with a LI-6400 portable photosynthesis system (Li-COR, Inc. Lincoln, NE, USA) with a standard leaf chamber equipped with a 6400-02B LED light source (LI-6400, Li-COR, Lincoln, NE, USA). Measurements were conducted at an air concentration of $21 \% \mathrm{O}_{2}, 400 \mu \mathrm{mol} \mathrm{mol}{ }^{-1}$ carbon dioxide $\left(\mathrm{CO}_{2}\right), 800 \mu \mathrm{mol} \mathrm{m}{ }^{-2} \mathrm{~s}^{-1}$ PAR, $50 \%$ relative humidity and a temperature of $20 \pm 2^{\circ} \mathrm{C}$. The gas exchange measurements were performed on sunny days from 8:30 to 11:30 am.

Chlorophyll fluorescence $(\mathrm{Fv} / \mathrm{Fm})$ was determined in the morning (08:00 am-11:00 am) on the healthy and fully developed leaves with a pulse modulation fluorometer (PAM-2500, Walz, Effeltrich, Germany). After $30 \mathrm{~min}$ of adaptation to the dark (Tang et al., 2015), the minimum fluorescence (Fo) was determined in a measuring light of approximately $0.5 \mu \mathrm{mol}$ photon $\mathrm{m}^{-2} \mathrm{~s}^{-1}$, and the maximum fluorescence (Fm) was determined under a 0.8 -s saturating flash of $10,000 \mu \mathrm{mol}$ photon $\mathrm{m}^{-2} \mathrm{~s}^{-1}$. The $\mathrm{Fv} / \mathrm{Fm}$ value was calculated as $(\mathrm{Fm}-\mathrm{Fo}) / \mathrm{Fm}$ (Maxwell and Johnson, 2000).

\section{Determination of Root Morphological Traits}

After gently washing the roots with deionized water, the total length, volume, and surface area of the root samples were determined by image analysis. The roots were photographed 

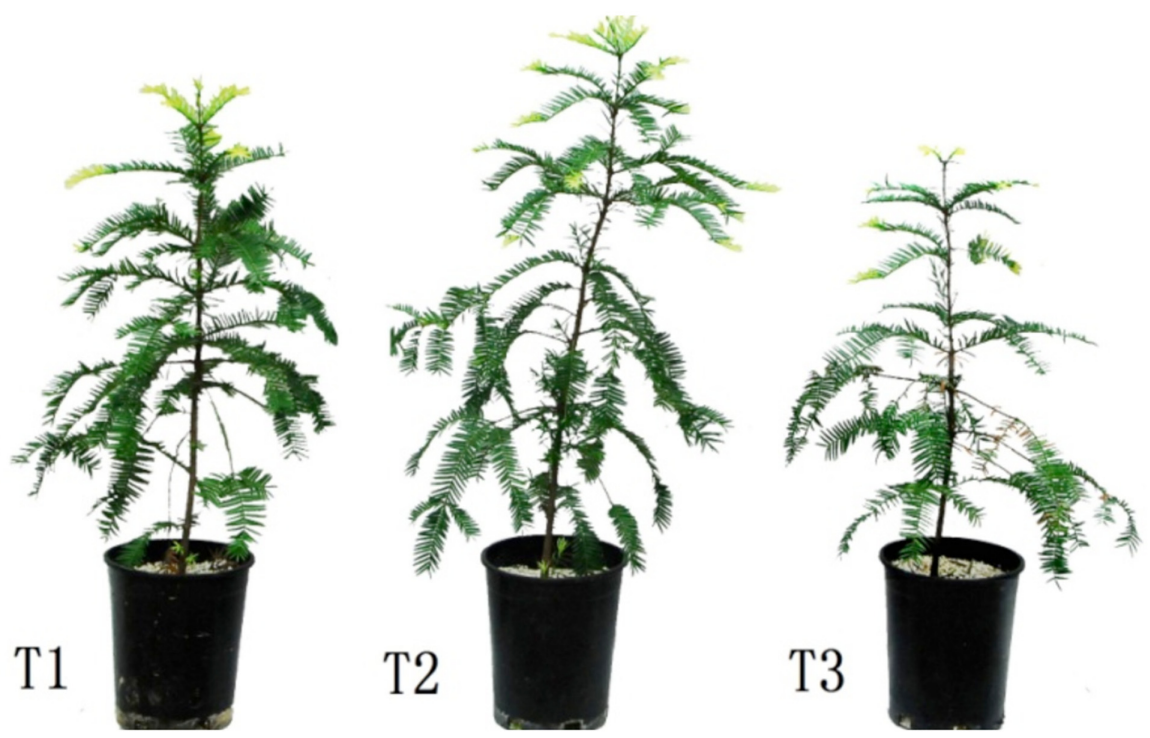

FIGURE 1 | Effect of $\mathrm{Pb}^{2+}$ addition to the growth medium on T. grandis seedlings. $\mathrm{T} 1$, control, $\mathrm{T} 2,700 \mathrm{mg} \mathrm{kg}^{-1} \mathrm{~Pb}^{2+}, \mathrm{T}_{3}, 1400 \mathrm{mg} \mathrm{kg}-1$ Pb2+.

and then the images were analyzed with the root image analysis system software WinRHIZO ${ }^{1}$.

\section{Root Oxidative Activity}

The root oxidative activity was measured according to the method of Mishra (2012) with a slight modification. About $3 \mathrm{~g}$ fresh root were immersed in $300 \mathrm{ml}$ of $20 \mathrm{ppm}$ ánaphthylamine solution for 10 minutes to exclude any initial rapid absorption of á-naphthylamine by roots. The intact roots were then transferred to another vial with $300 \mathrm{ml}$ of $20 \mathrm{ppm}$ of á-naphthylamine solution and incubated for four hours at $25 \pm 1^{\circ} \mathrm{C}$. Then, $2 \mathrm{ml}$ of the incubated solution were mixed with $10 \mathrm{ml}$ of $0.1 \%$ sulfanilic acid (in $3 \%$ acetic acid) and $2 \mathrm{ml}$ of $50 \mathrm{ppm} \mathrm{NaNO}_{2}$, and diluted to $25 \mathrm{ml}$ using distilled water. The absorbance of the colored solution was determined at $530 \mathrm{~nm}$ using spectrophotometry. Root oxidative activity was expressed as $\mu \mathrm{g}$ á-naphthylamine $\mathrm{h}^{-1} \mathrm{~g}^{-1} \mathrm{FW}$.

\section{Ultrastructure of Chloroplast and Root}

To examine the chloroplast ultrastructure of mesophyll cells, fresh leaves were immediately fixed in $2.5 \%(\mathrm{v} / \mathrm{v})$ glutaraldehyde (0.1 mol L ${ }^{-1}$ phosphate buffer, $\mathrm{pH}$ 7.2) for at least $48 \mathrm{~h}$ after detachment from the plants. The samples were immersed in $1 \%(\mathrm{v} / \mathrm{v})$ osmium acid for post-fixation, embedded in resin, and ultrathin sectioned for transmission electron microscopy ( $\mathrm{H} 7650$, Hitachi, Tokyo, Japan).

\section{Data Analysis}

Because the $\mathrm{Pb}^{2+}$ and $\mathrm{Mg}^{2+}$ treatments were not applied independently to each seedling, the plants in each treatment combination were not true replicates (Hurlbert, 1984; Maherali

${ }^{1}$ www.regentinstruments.com and DeLucia, 2000). Therefore, averages of subsamples (five seedlings per replicate) were used for the analysis of variance. All measurements were tested by a one-way ANOVA for the effects of treatments (combinations of $\mathrm{Pb}^{2+}$ and $\mathrm{Mg}^{2+}$ concentration). The effects were considered significant at $P<0.05$. Before ANOVA, data were checked for normality and homogeneity of variances, and log-transformed to correct deviations from these assumptions when needed. Significant differences among treatment means were analyzed using Tukey's multiple comparison post hoc tests. The used statistical software package was SPSS 16 for Windows (SPSS Inc., Chicago, IL, USA).

\section{RESULTS}

\section{Effect of Lead on Plant Growth and Development}

Plants grown for 60 days at 0,700 , and $1400 \mathrm{mg} \mathrm{Pb}^{2+}$ per kg-1 soil could be visually differentiated. Plants grown at $700 \mathrm{mg}$ $\mathrm{kg}^{-1}$ were larger than those of other treatments (Figure 1). Compared with the control, soil contamination of $700 \mathrm{mg} \mathrm{\textrm {Pb } ^ { 2 + }}$ $\mathrm{kg}^{-1}$ significantly increased the growth of $T$. grandis seedlings $\left(P=0.0001\right.$, Figure 2). However, the $1400 \mathrm{mg} \mathrm{kg}^{-1} \mathrm{~Pb}^{2+}$ treatment inhibited plant growth and ground diameter by $60.5 \%$ $(P=0.0001)$ and $83.0 \%(P=0.0001)$, respectively (Figure 2$)$.

\section{Effect of $\mathrm{Mg}^{2+}$ on Dry Biomass, Plant Growth, and Morphological Traits of Roots Under Lead Toxicity}

Compared with the control seedlings, exposure of plants to $1400 \mathrm{mg} \mathrm{kg} \mathrm{kb}^{-1}$ in a growth medium for 60 days significantly decreased the dry mass of shoots and roots by $19.6 \%(P=0.0002)$ and $24.1 \%(P=0.0038)$, respectively 


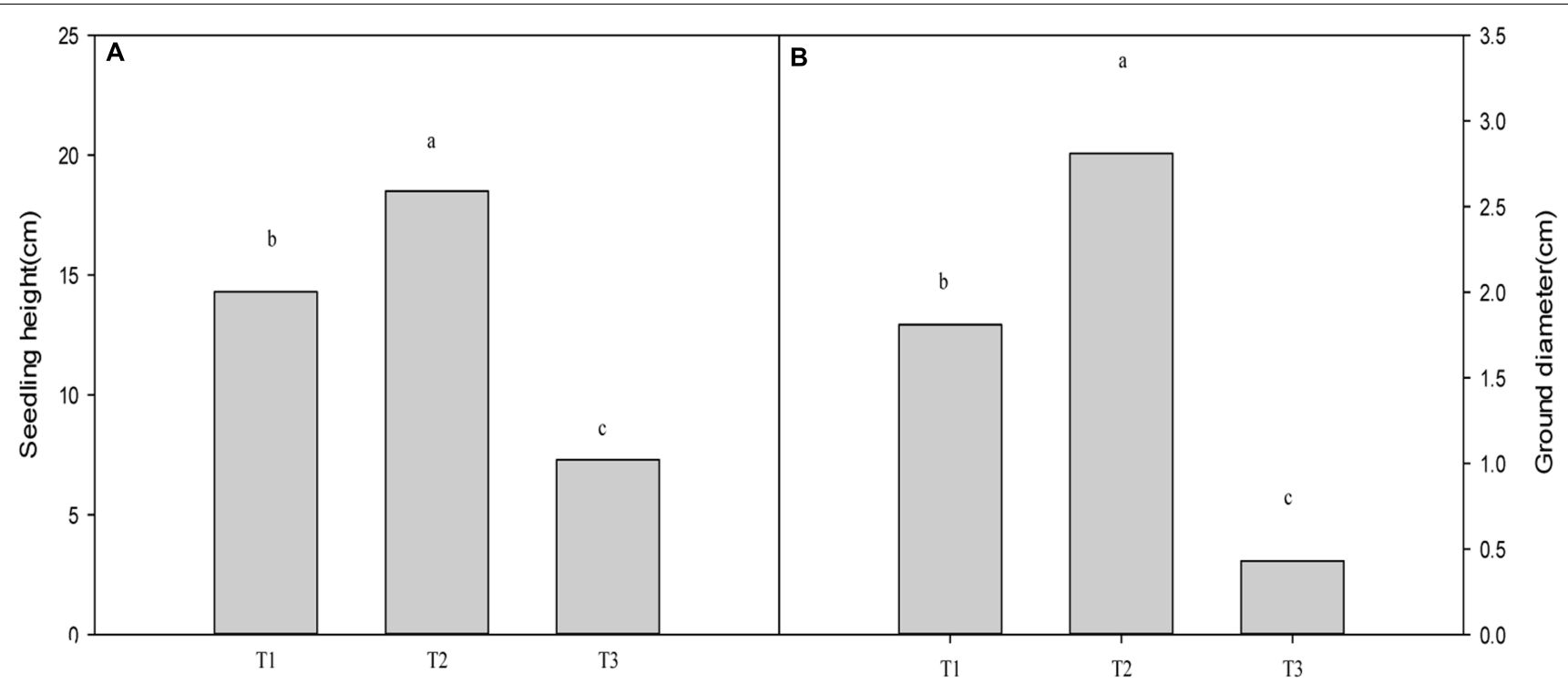

FIGURE 2 | Effect of $\mathrm{Pb}^{2+}$ addition to growth medium on the seedling height (A) and ground diameter (B) of T. grandis seedlings. T1, control, T2, $700 \mathrm{mg}$ $\mathrm{kg}^{-1} \mathrm{~Pb}^{2+}, \mathrm{T} 3,1400 \mathrm{mg} \mathrm{kg}^{-1} \mathrm{~Pb}^{2+}$. Data points and error bars represent mean \pm standard deviation $(n=3)$. Different lower case letters above the columns indicate significant $(P<0.05)$ difference between treatments.

(Table 1). The $\mathrm{Mg}^{2+}$-treated plants had significantly higher shoot $(P=0.0172)$ and $\operatorname{root}(P=0.0118)$ dry mass than plants under $\mathrm{Pb}^{2+}$ toxicity without $\mathrm{Mg}^{2+}$ application (Table 1). However, $\mathrm{Mg}^{2+}$ had no significant effect on the dry mass of shoots $(P=0.5937)$ and roots $(P=0.9235)$ of the non- $\mathrm{Pb}^{2+}$-stressed plants. The leaf area $(P=0.0001)$ and seedling height $(P=0.0001)$ of plants under $\mathrm{Pb}^{2+}$ toxicity were significantly lower than those of the control plants. Application of $\mathrm{Mg}^{2+}$ increased the leaf area $(P=0.0004)$ and seedling height $(P=0.0001)$ of plants under $\mathrm{Pb}^{2+}$ toxicity $(P<0.05$, Table 1). However, there were no significant differences in leaf area $(P=0.4141)$ and seedling height $(P=0.1411)$ in the non-lead-stressed plants treated with or without $\mathrm{Mg}^{2+}$.

Total length, surface area and volume of plant roots under $\mathrm{Pb}^{2+}$ toxicity decreased significantly by $26.9 \%(P=0.0004)$, 28.8\% $(P=0.0001)$, and $33.5 \%(P=0.0001)$, respectively, compared with the control plants (Table 1). Treatment of $\mathrm{Pb}^{2+}$-stressed plants with $\mathrm{Mg}^{2+}$ significantly increased total length, surface area and volume of roots by $27.7 \%$ $(P=0.0029), 24.3 \%(P=0.0113)$, and $24.0 \%(P=0.0001)$, respectively, compared with plants treated only with $\mathrm{Pb}^{2+}$ for 60 days.

\section{Effect of $\mathrm{Mg}^{2+}$ on Photosynthetic Pigments and Gas Exchange Parameters of Plants Under Lead Toxicity}

Variations in the levels of photosynthetic pigments, including chlorophyll a (Chla), chlorophyll b (Chlb), and carotenoids (Car), were evaluated in T. grandis seedlings under lead toxicity (Table 2$)$. The Chla $(P=0.0001)$ concentrations, Chlb $(P=0.0001)$ concentrations, Car $(P=0.0004)$ concentrations and Chla/Chlb $(P=0.0003)$ ratios were lower but the Car/Chl $(\mathrm{a}+\mathrm{b})(P=0.0003)$ ratios were higher in the $\mathrm{Pb}^{2+}$ treated plants than in the control plants. Application of $\mathrm{Mg}^{2+}$ resulted in higher Chla $(P=0.0001)$, Chlb $(P=0.0001)$, and $\operatorname{Car}(P=0.0019)$ concentrations, and also increased the Chla/b $(P=0.0012)$ ratios but lowered the Car/Chl $(\mathrm{a}+\mathrm{b})$

TABLE 1 | Effects of $\mathrm{Mg}^{2+}$ on the dry biomass of shoots and roots, leaf area (LA), seedling height, and root morphological traits of $T$. grandis seedlings grown under $\mathrm{Pb}^{2+}$ toxicity.

\begin{tabular}{|c|c|c|c|c|c|c|c|}
\hline Treatment & $\begin{array}{c}\text { Shoot } \\
\text { Biomass (g) }\end{array}$ & $\begin{array}{c}\text { Root } \\
\text { Biomass (g) }\end{array}$ & $\operatorname{LA}\left(\mathrm{cm}^{2}\right)$ & $\begin{array}{c}\text { Seedling } \\
\text { height }(\mathbf{c m})\end{array}$ & $\begin{array}{c}\text { Total root } \\
\text { length }(\mathrm{cm})\end{array}$ & $\begin{array}{l}\text { Root surface } \\
\text { area }\left(\mathrm{cm}^{2}\right)\end{array}$ & $\begin{array}{l}\text { Root volume } \\
\qquad\left(\mathrm{cm}^{3}\right)\end{array}$ \\
\hline T1 & $26.0 \pm 1.20^{a}$ & $11.6 \pm 0.64^{a}$ & $0.7 \pm 0.04^{a b}$ & $14.3 \pm 0.17^{a}$ & $1614.6 \pm 70.54^{a}$ & $865.2 \pm 7.42^{a}$ & $38.8 \pm 0.41^{a}$ \\
\hline $\mathrm{T} 2$ & $26.7 \pm 0.35^{a}$ & $11.9 \pm 0.21^{\mathrm{a}}$ & $0.8 \pm 0.02^{a}$ & $14.8 \pm 0.15^{a}$ & $1682.1 \pm 7.78^{a}$ & $919.7 \pm 5.45^{a}$ & $41.9 \pm 0.39^{a}$ \\
\hline T3 & $20.9 \pm 0.35^{c}$ & $8.8 \pm 0.49^{b}$ & $0.5 \pm 0.02^{\mathrm{c}}$ & $7.3 \pm 0.10^{c}$ & $1179.7 \pm 128.0^{b}$ & $616.4 \pm 8.48^{c}$ & $25.8 \pm 2.34^{\mathrm{C}}$ \\
\hline $\mathrm{T} 4$ & $23.4 \pm 0.78^{b}$ & $11.1 \pm 1.48^{a}$ & $0.7 \pm 0.01^{b}$ & $10.8 \pm 0.15^{b}$ & $1506.8 \pm 23.74^{a}$ & $766.8 \pm 14.90^{b}$ & $32.0 \pm 2.50^{b}$ \\
\hline
\end{tabular}

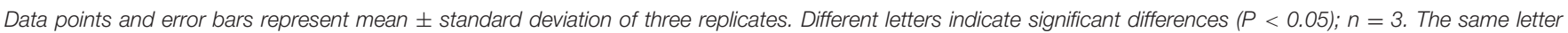

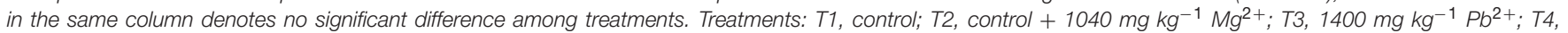
$1400 \mathrm{mg} \mathrm{kg}^{-1} \mathrm{~Pb}^{2+}+1040 \mathrm{mg} \mathrm{kg}^{-1} \mathrm{Mg}^{2+}$. 


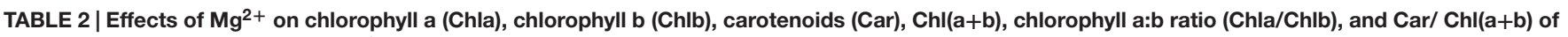
T. grandis seedling leaves under $\mathrm{Pb}^{2+}$ toxicity.

\begin{tabular}{|c|c|c|c|c|c|c|}
\hline Treatment & Chla (mg/g) & Chlb (mg/g) & Car (mg/g) & $\mathrm{Chl}(\mathrm{a}+\mathrm{b})(\mathrm{mg} / \mathrm{g})$ & Chla/Chlb & Car/Chl(a+b) \\
\hline $\mathrm{T} 1$ & $1.0 \pm 0.01^{a}$ & $0.5 \pm 0.01^{a}$ & $0.3 \pm 0.01^{a}$ & $1.5 \pm 0.01^{a}$ & $2.1 \pm 0.02^{a}$ & $0.2 \pm 0.01^{b}$ \\
\hline $\mathrm{T} 2$ & $1.0 \pm 0.03^{a}$ & $0.5 \pm 0.02^{a}$ & $0.3 \pm 0.01^{a}$ & $1.5 \pm 0.04^{a}$ & $2.1 \pm 0.07^{a}$ & $0.2 \pm 0.02^{b}$ \\
\hline T3 & $0.5 \pm 0.02^{c}$ & $0.3 \pm 0.01^{b}$ & $0.2 \pm 0.02^{b}$ & $0.8 \pm 0.02^{c}$ & $1.8 \pm 0.02^{\mathrm{C}}$ & $0.3 \pm 0.03^{a}$ \\
\hline $\mathrm{T} 4$ & $0.9 \pm 0.04^{b}$ & $0.5 \pm 0.02^{a}$ & $0.3 \pm 0.02^{a}$ & $1.4 \pm 0.03^{b}$ & $2.0 \pm 0.04^{b}$ & $0.2 \pm 0.01^{b}$ \\
\hline
\end{tabular}

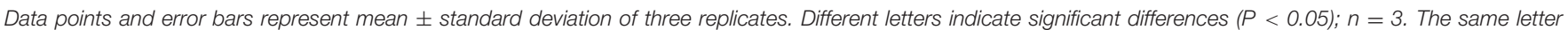

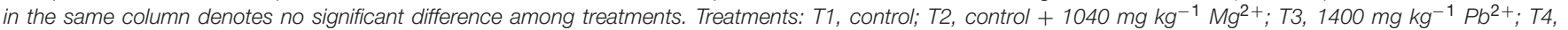
$1400 \mathrm{mg} \mathrm{kg}^{-1} \mathrm{~Pb}^{2+}+1040 \mathrm{mg} \mathrm{kg}^{-1} \mathrm{Mg}^{2+}$.
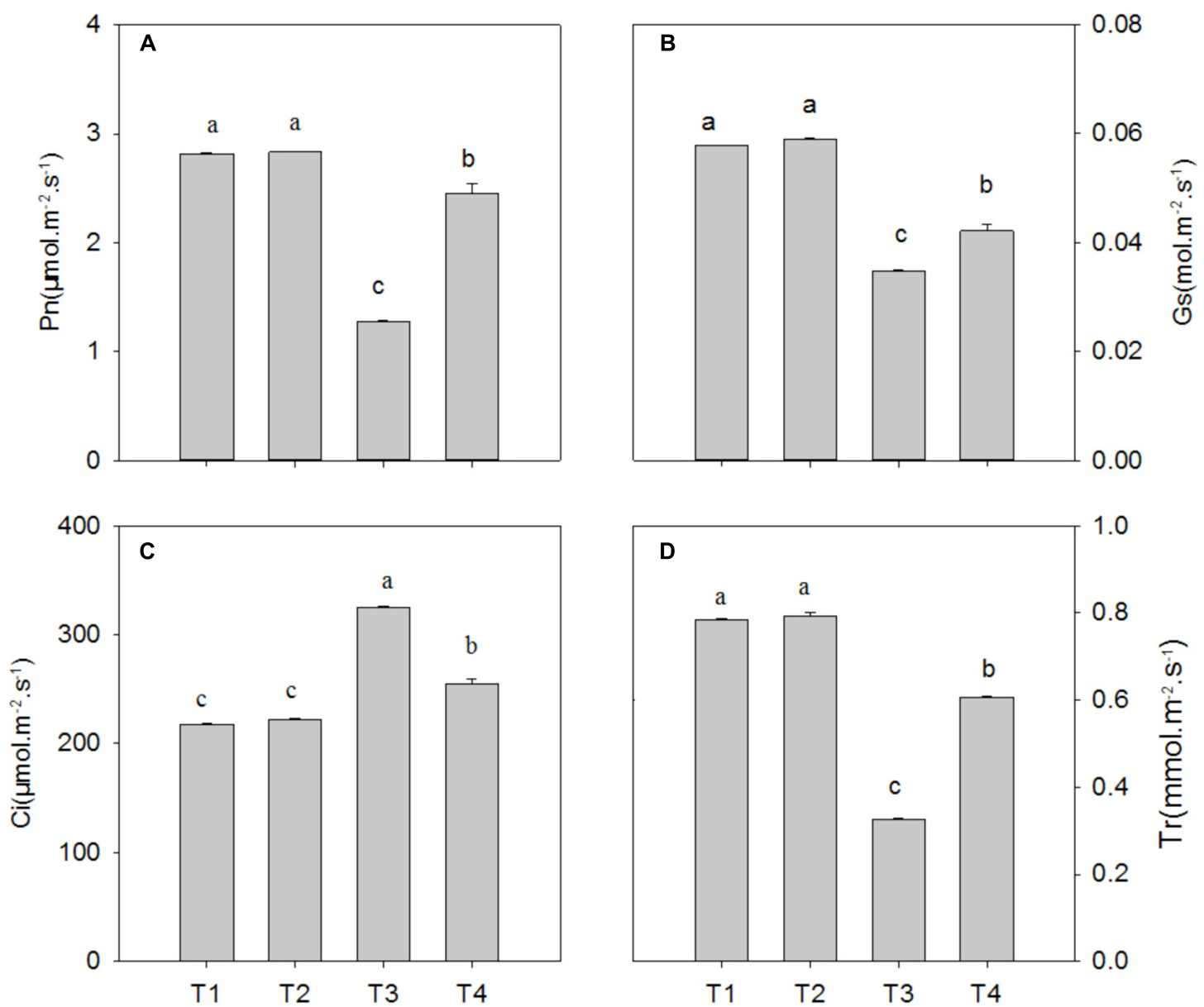

FIGURE 3 | The net photosynthetic rate (Pn) (A), stomatal conductance (Gs) (B), internal carbon dioxide concentration (Ci) (C), and transpiration rate (Tr) (D) of T. grandis seedlings grown in media amended with various amounts of $\mathrm{Pb}^{2+}$ and $\mathrm{Mg}^{2+}$. Treatments: $\mathrm{T} 1$, control; $\mathrm{T}_{2}$, control $+1040 \mathrm{mg} \mathrm{kg}{ }^{-1} \mathrm{Mg}^{2+} ; \mathrm{T}^{2}, 1400 \mathrm{mg}$ $\mathrm{kg}^{-1} \mathrm{~Pb}^{2+} ; \mathrm{T} 4,1400 \mathrm{mg} \mathrm{kg}^{-1} \mathrm{~Pb}^{2+}+1040 \mathrm{mg} \mathrm{kg}^{-1} \mathrm{Mg}^{2+}$. Error bars are standard deviation $(n=3)$. Different lower case letters above the columns indicate significant $(P<0.05)$ difference between treatments.

$(P=0.0005)$ ratios in the leaves of plants exposed to $1400 \mathrm{mg} \mathrm{kg}^{-1} \mathrm{~Pb}^{2+}$ (Table 2). However, significant difference in chlorophyll and carotenoid concentrations between seedlings treated with and without $\mathrm{Mg}^{2+}$ under no $\mathrm{Pb}^{2+}$ toxicity was not found.

Compared with the control, $\mathrm{Pb}^{2+}$ toxicity significantly decreased the photosynthetic rate $(\mathrm{Pn})$, stomatal conductance
(Gs) and transpiration ( $\mathrm{Tr})$ by $54.6 \%(P=0.0001), 39.8 \%$ $(P=0.0001)$, and $58.4 \%(P=0.0001)$, respectively, while it increased intercellular $\mathrm{CO}_{2}(\mathrm{Ci})$ by $49.1 \%(P=0.0001)$ (Figure 3; $P<0.05)$. In leaves of plants under $\mathrm{Pb}^{2+}$ toxicity, $\mathrm{Mg}^{2+}$ treatment significantly increased the levels of Pn, Gs, and Tr by 91.8\% $(P=0.0001), 21.0 \%(P=0.0001)$, and $86.4 \%(P=0.0001)$, respectively, whereas it decreased Ci levels by $21.4 \%(P=0.0001)$ 
compared with non- $\mathrm{Mg}^{2+}$-treated plants under $\mathrm{Pb}^{2+}$ toxicity (Figure 3).

\section{Effect of $\mathrm{Mg}^{2+}$ on Chlorophyll Fluorescence and Oxidative Activity of Roots in Plants Under Lead Toxicity}

The Fv/Fm value was significantly decreased by $21.6 \%$ $(P=0.0001)$ in plants under $\mathrm{Pb}^{2+}$ toxicity compared with the control (Figure 4B). Application of $\mathrm{Mg}^{2+}$ significantly increased the Fv/Fm value by $23.7 \%(P=0.0001)$ in leaves of seedlings exposed to $1400 \mathrm{mg} \mathrm{kg}^{-1} \mathrm{~Pb}^{2+}$ (Figure 4A).

The root oxidative activity in plants under $\mathrm{Pb}^{2+}$ toxicity decreased compared with the control $(P=0.0001$, Figure 4B). Application of $\mathrm{Mg}^{2+}$ to $\mathrm{Pb}^{2+}$-stressed plants significantly increased root oxidative activity by $102.9 \%(P=0.0001)$ compared with plants only treated with $\mathrm{Pb}^{2+}$ (Figure 4A). However, significant difference in oxidative activity between plants treated with and without $\mathrm{Mg}$ under no $\mathrm{Pb}^{2+}$ toxicity was not found ( $P=0.4361$, Figure 4B).

\section{Effect of $\mathrm{Mg}^{2+}$ on $\mathrm{Pb}^{2+}$ and $\mathrm{Mg}^{2+}$ Accumulation in Plant Tissues Under Lead Toxicity}

Under $\mathrm{Pb}^{2+}$ toxicity, $\mathrm{Pb}^{2+}$ contents in the roots were three times higher than in the shoots, indicating that the roots accumulated the majority of the absorbed $\mathrm{Pb}^{2+}$. After application of $\mathrm{Mg}^{2+}$, the $\mathrm{Pb}^{2+}$ concentrations in the roots were higher than in roots of the $\mathrm{Pb}^{2+}$-stressed plants, whereas the $\mathrm{Pb}^{2+}$ uptake in the aboveground parts was lower compared to the plants without $\mathrm{Mg}^{2+}$ application. Interestingly, the distribution of $\mathrm{Mg}^{2+}$ in roots and shoots of the T. grandis seedlings differed significantly. The $\mathrm{Mg}^{2+}$ concentration in the shoots of the control plants was higher than in the roots. However, $\mathrm{Pb}^{2+}$ toxicity had no significant effect on the distribution of $\mathrm{Mg}^{2+}$ between roots $(P=0.6412)$ and shoots $(P=0.8785)$ compared with the control. Application of $\mathrm{Mg}^{2+}$ significantly increased $\mathrm{Mg}^{2+}$ accumulation in the shoots $(P=0.0001)$ and roots $(P=0.0002)$, and $\mathrm{Mg}^{2+}$ concentration was four times higher in the shoots than in the roots (Table 3 ).

\section{Effect of $\mathrm{Mg}^{2+}$ on Ultrastructural Modifications of Leaves and Roots in Plants Under Lead Toxicity}

Application of $\mathrm{Mg}^{2+}$ caused significant differences in the ultrastructure of the chloroplasts of the T. grandis seedlings grown under $\mathrm{Pb}^{2+}$ toxicity (Figure 5). Elliptical-shaped chloroplasts with thylakoids were found in the control plants. However, the integrity of the ultrastructure was severely affected by $\mathrm{Pb}^{2+}$ toxicity. Chloroplasts were swollen and had irregularly shaped grana, decreased lamellae, and increased osmiophilic granule numbers, and the thylakoid membrane system in plants was in disorder. Interestingly, application of $\mathrm{Mg}^{2+}$ promoted the development of chloroplasts, grana and stroma lamellae as well as reduced the osmiophilic granule numbers.

Lead toxicity had a marked influence on the ultrastructure of the seedlings' roots (Figure 6). Compared with the control, the root cell structure under lead toxicity was completely destroyed. The nucleus was almost invisible and the mitochondria appeared as hollow bubbles. Application of $\mathrm{Mg}^{2+}$ protected the integrity of the root cells as evidenced by visible nuclei, slightly condensed chromatin and irregularly swollen mitochondria with fractured and fuzzy cristae.

\section{DISCUSSION}

The growth of $T$. grandis seedlings was highest at $700 \mathrm{mg} \mathrm{kg}^{-1}$ $\mathrm{Pb}^{2+}$ in soil, whereas the lowest growth of plants was found at $1400 \mathrm{mg} \mathrm{kg}^{-1} \mathrm{~Pb}^{2+}$ (Figures 1 and 2), indicating that lead stress toxicity in T. grandis seedlings did not occur at $700 \mathrm{mg} \mathrm{kg}^{-1}$ $\mathrm{Pb}^{2+}$ in soil. Meanwhile, visible toxic symptoms, such as old leaves yellowing and chlorosis, were observed in plants exposed to $1400 \mathrm{mg} \mathrm{kg}^{-1} \mathrm{~Pb}^{2+}$ (Figure 1). The treatment with $1400 \mathrm{mg} \mathrm{kg}^{-1}$ $\mathrm{Pb}^{2+}$ significantly decreased plant growth and the development of the $T$. grandis seedlings, as indicated by the decreased shoot dry mass, root dry mass, seedling height and leaf area (Table 1 ). Similarly, Hadi et al. (2010) found that $500 \mathrm{mg} \mathrm{kg}^{-1} \mathrm{~Pb}^{2+}$ in soil did not affect the germination rate of maize (Zea mays) seeds and that the young maize seedlings did not exhibit any visible toxic symptoms.

Chlorophyll fluorescence is the focus in studies of photosynthetic regulation and plant responses to the environment due to its sensitivity, convenience and nondestructive characteristics (Dai et al., 2009). Generally, plants subjected to heavy metal stress typically have lower Fv/Fm values than non-stressed plants, which is associated with photoinhibition of PSII (Krause and Weis, 1991; Wu et al., 2014). In the present study, the $\mathrm{Fv} / \mathrm{Fm}$ ratio was significantly reduced in the plants treated with $1400 \mathrm{mg} \mathrm{kg}^{-1} \mathrm{~Pb}^{2+}$ (Figure 4A). Indeed, this result was consistent with the gas exchange results, in which lead toxicity decreased $\mathrm{Pn}, \mathrm{Tr}$ and Gs compared with the control (Figure 3), indicating photoinhibition of the photosynthetic capacity in $T$. grandis seedlings under lead stress conditions. A similar result was also described by Rashid and Popovic (1990) for spinach leaves treated with $2 \mathrm{mM}$ $\mathrm{Pb}^{2+}$. Interestingly, in this study the $\mathrm{Ci}$ value was higher in $\mathrm{Pb}^{2+}$-treated plants than in the control plants, indicating that the reduction of photosynthesis under lead stress conditions primarily resulted from non-stomatal limitations. Additionally, photoinhibition and reduction of the photosynthetic capacity under lead stress conditions were manifested by changes of leaf chlorophyll contents. This was explained by its important role in photosynthesis and plant growth. In the present study, we found a strong reduction in the levels of Chla, Chlb, total $\mathrm{Chl}$ content and carotenoids in plants treated with $1400 \mathrm{mg}$ $\mathrm{kg}^{-1} \mathrm{~Pb}^{2+}$ (Table 2), which was consistent with the results of de Souza et al. (2012), who reported that $\mathrm{Pb}^{2+}$ exposure led to a reduction of Chla and Chlb contents in leaves as well as a reduction of Car levels. Application of $\mathrm{Mg}^{2+}$ to $\mathrm{Pb}^{2+}$-stressed plants improved plant growth, which was accompanied with increased chlorophyll contents, Pn levels and $\mathrm{Fv} / \mathrm{Fm}$ ratios (Tables 1 and 2; Figures 3 and $4 \mathrm{~A}$ ). Thus, the positive and beneficial effects of $\mathrm{Mg}^{2+}$ on the growth of T. grandis seedlings 


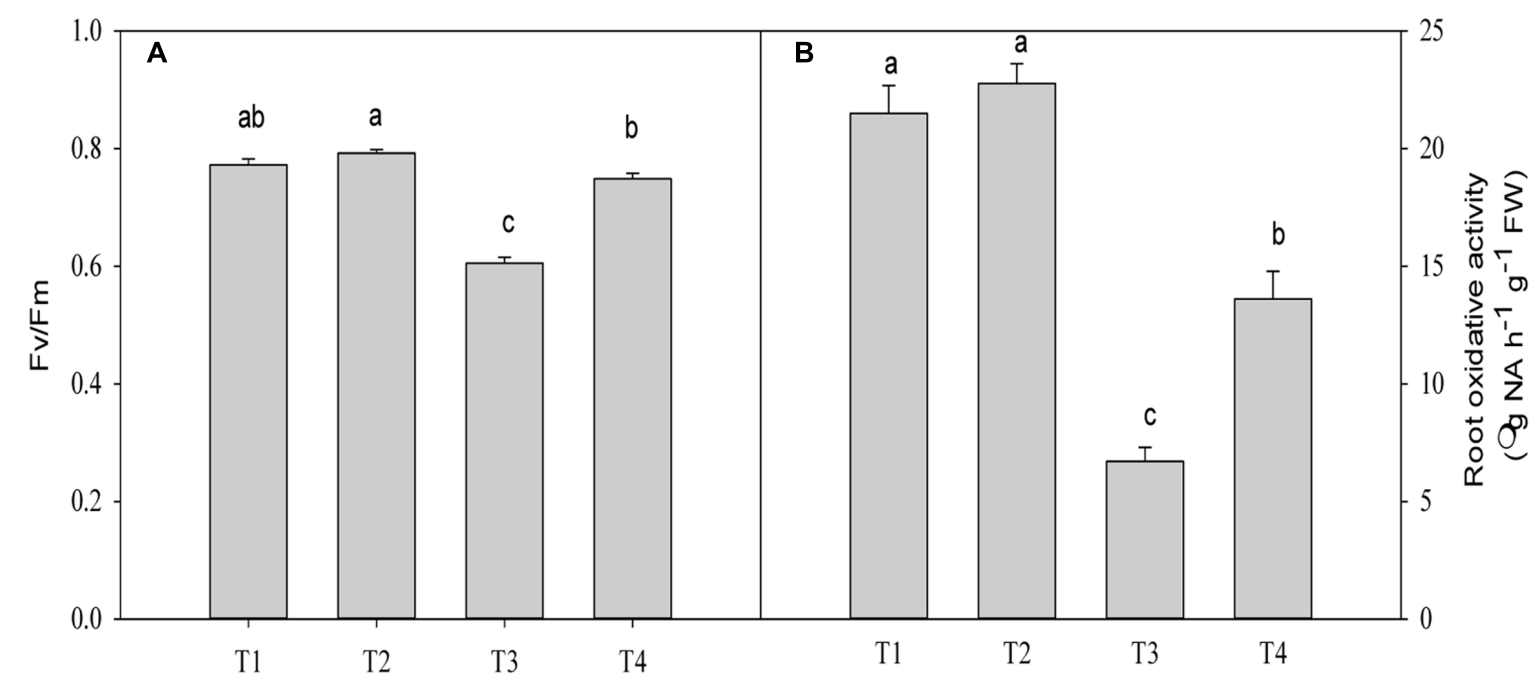

FIGURE 4 | The maximum quantum efficiency (Fv/Fm) (A) and root oxidative activity (B) of T. grandis seedlings grown in media amended with various amounts

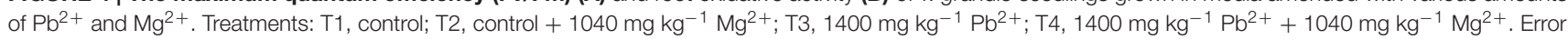
bars are standard deviation $(n=3)$. Different lower case letters above the columns indicate significant $(P<0.05)$ difference between treatments.

might be associated with improving the photosynthetic capacity and alleviating photoinhibition. A similar result was reported by Hermans et al. (2011), who indicated that the protective effect of $\mathrm{Mg}^{2+}$ against Cd toxicity may be at least partly attributed to the protection of the photosynthetic apparatus. It is well known that photoinhibition primarily results from overproduction of reactive oxygen species (ROS) through the photosynthetic electron transport chain under stress circumstances (Critchley, 1981). However, it needs to be further elucidated if $\mathrm{Mg}^{2+}$ protects the photosynthetic membrane from photo-oxidation by effectively scavenging ROS under lead stress conditions.

The influence of heavy metal on cellular organization is important for understanding physiological alterations under stress conditions (Souza et al., 2005). In the present study, chloroplasts were highly susceptible to stress induced by high lead conditions, as indicated by decreased lamellae, increased numbers of osmiophilic granules and disrupted thylakoid membranes (Figure 5). Damage to chloroplasts and thylakoid membranes in plants treated with heavy metals has been reported

TABLE 3 | Effects of $\mathrm{Mg}^{2+}$ on concentrations of $\mathrm{Pb}^{2+}$ and $\mathrm{Mg}^{2+}$ in shoots and roots of $T$. grandis seedlings grown under $\mathrm{Pb}^{2+}$ toxicity.

\begin{tabular}{|c|c|c|c|c|}
\hline Treatment & $\begin{array}{c}\mathrm{Pb}^{2+} \text { content } \\
\left(\mathrm{mg} \mathrm{kg}^{-1}\right) \text { Root }\end{array}$ & Shoot & $\begin{array}{l}\mathrm{Mg}^{2+} \text { content } \\
\left(\mathrm{mg} \mathrm{g}^{-1}\right) \text { Root }\end{array}$ & Shoot \\
\hline $\mathrm{T} 1$ & n.d. & n.d. & $0.39 \pm 0.03^{b}$ & $0.74 \pm 0.03^{b}$ \\
\hline $\mathrm{T} 2$ & n.d. & n.d. & $0.73 \pm 0.08^{a}$ & $3.27 \pm 0.05^{a}$ \\
\hline T3 & $689.1 \pm 30.5^{b}$ & $231.4 \pm 12.3^{a}$ & $0.44 \pm 0.05^{b}$ & $0.79 \pm 0.02^{b}$ \\
\hline $\mathrm{T} 4$ & $876.1 \pm 20.2^{a}$ & $156.2 \pm 3.6^{b}$ & $0.76 \pm 0.01^{a}$ & $3.37 \pm 0.2^{a}$ \\
\hline
\end{tabular}

Data points and error bars represent mean \pm standard deviation of three replicates. Different letters indicate significant differences $(P<0.05) ; n=3$. The same letter in the same column denotes no significant difference among treatments, n.d. = not determined. Treatments: T1, control; T2, control + $1040 \mathrm{mg} \mathrm{kg}^{-1} \mathrm{Mg}^{2+}$; T3, $1400 \mathrm{mg} \mathrm{kg}^{-1} \mathrm{~Pb}^{2+}$; T4, $1400 \mathrm{mg} \mathrm{kg}^{-1} \mathrm{~Pb}^{2+}+1040 \mathrm{mg} \mathrm{kg}^{-1} \mathrm{Mg}^{2+}$. by $\mathrm{Wu}$ et al. (2014). We found that $\mathrm{Mg}^{2+}$ ameliorated the chloroplast ultrastructural disorders caused by lead (Figure 5D), which might explain the improved photosynthesis of the Mgtreated plants. Meanwhile, as also suggested by our study, the main processes underlying the improvement in plant photosynthesis induced by $\mathrm{Mg}^{2+}$ treatment are the enhanced light-use-efficiency and the protection of the chloroplast structures.

Many scientists have reported that $\mathrm{Mg}^{2+}$ supplementation enhances the tolerance to toxic metals by reducing the uptake and translocation of metals, including $\mathrm{Cd}^{2+}$ and $\mathrm{Al}^{3+}$ (Kashem and Kawai, 2007; Bose et al., 2011). We found that the accumulation of lead was greater in the roots than in the shoots of $T$. grandis seedlings (Table 3 ), indicating that the plants translocated lower concentrations of metals into the shoots (Yang et al., 1998). Higher $\mathrm{Pb}^{2+}$ concentrations in roots than shoots were observed in the $\mathrm{Mg}^{2+}$-alleviated plants, whereas the shoot $\mathrm{Mg}^{2+}$ concentrations were four-fold higher than the root $\mathrm{Mg}^{2+}$ concentrations in the $\mathrm{Mg}^{2+}$-alleviated plants (Table 3). These results suggest that $\mathrm{Mg}^{2+}$ application through the watering solution helped decrease the $\mathrm{Pb}^{2+}$ accumulation in the shoots. Similar findings have been reported by Kashem and Kawai (2007), who found that magnesium-alleviated plants showed decreased shoot $\mathrm{Cd}^{2+}$ concentration in Japanese mustard spinach (Brassica rapa L. var. pervirdis).

Furthermore, lead uptake significantly reduced total root length, surface area and volume compared with the control plants (Table 1). However, the application of $\mathrm{Mg}^{2+}$ increased the indices of root morphological traits of $T$. grandis seedlings under lead toxicity. Root oxidative activity implies the degree of root development and metabolic status (Liu et al., 2008). In the present study, lower root oxidative activity was found in T. grandis seedlings under $\mathrm{Pb}^{2+}$ toxicity than in the non- $\mathrm{Pb}^{2+}$ treated control plants, whereas higher root oxidative activity was 

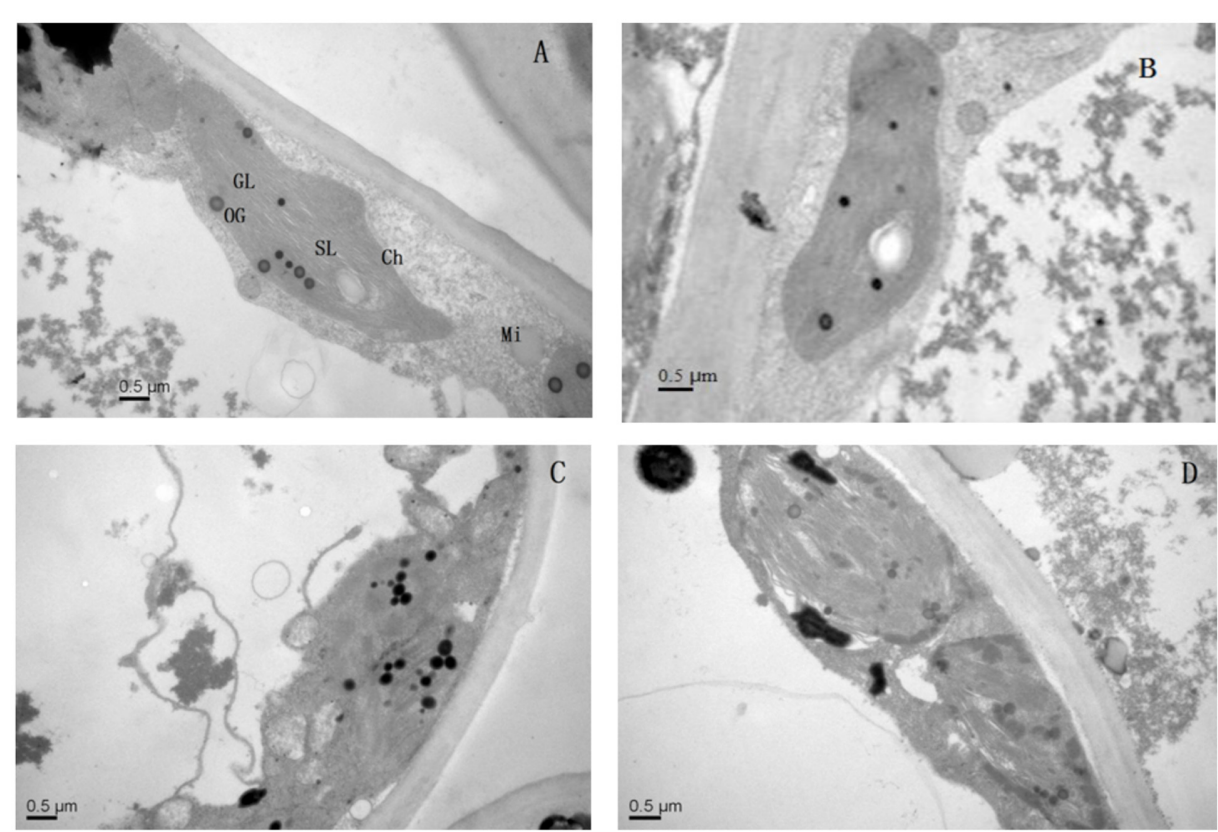

FIGURE 5 | The transmission electron micrographs of chloroplasts in $\mathbf{T}$. grandis seedlings grown in media amended with various amounts of $\mathrm{Pb}^{2+}$ and $\mathrm{Mg}^{2+}$. (A) Control; (B) control + $1040 \mathrm{mg} \mathrm{kg}^{-1} \mathrm{Mg}^{2+}$; (C) $1400 \mathrm{mg} \mathrm{kg}^{-1} \mathrm{~Pb}^{2+}$; (D) $1400 \mathrm{mg} \mathrm{kg}^{-1} \mathrm{~Pb}^{2+}+1040 \mathrm{mg} \mathrm{kg}^{-1} \mathrm{Mg}^{2+}$.
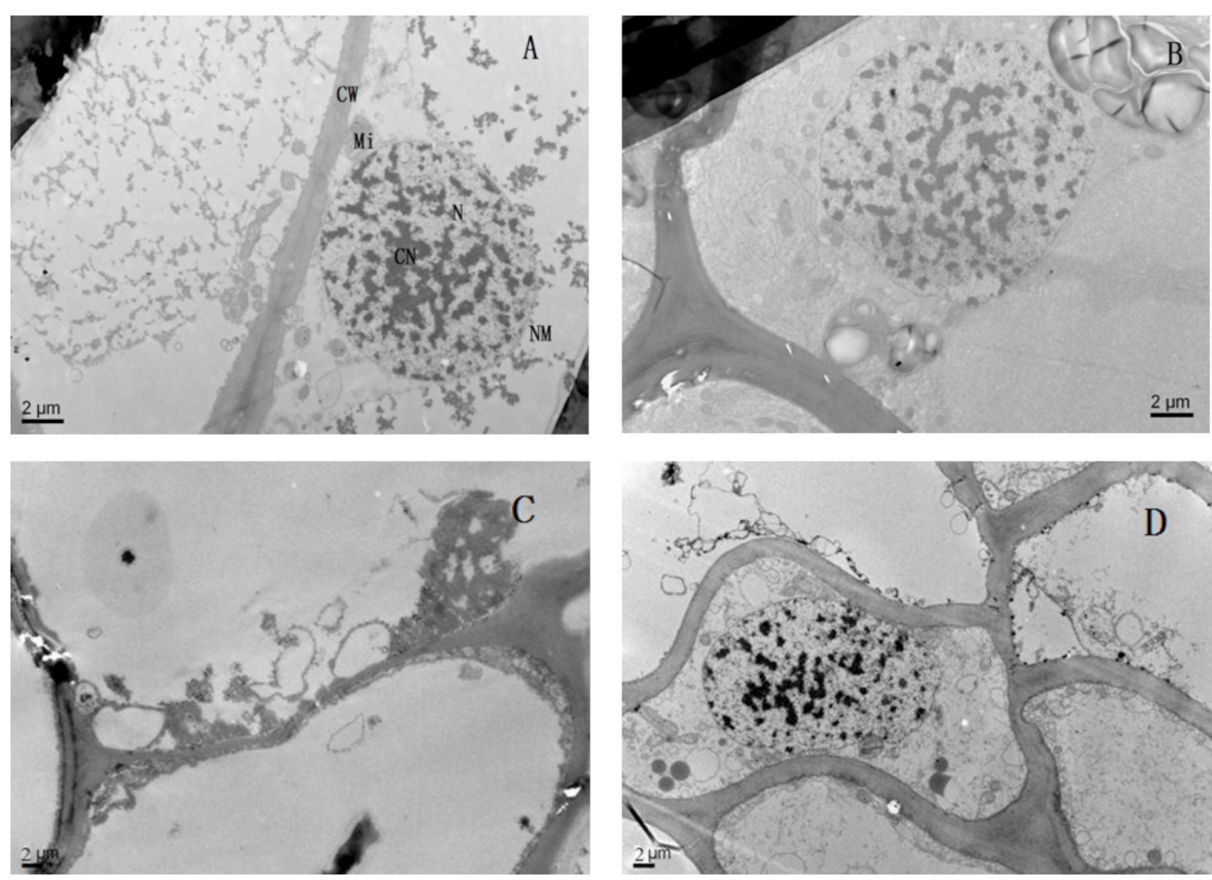

FIGURE 6 | The transmission electron micrographs of root of $T$. grandis seedlings grown in media amended with various amounts of $\mathrm{Pb}^{2+}$ and $\mathrm{Mg}^{2+}$. (A) Control; (B) control + $1040 \mathrm{mg} \mathrm{kg}^{-1} \mathrm{Mg}^{2+}$; (C) $1400 \mathrm{mg} \mathrm{kg}^{-1} \mathrm{~Pb}^{2+}$; (D) $1400 \mathrm{mg} \mathrm{kg}^{-1} \mathrm{~Pb}^{2+}+1040 \mathrm{mg} \mathrm{kg}^{-1} \mathrm{Mg}^{2+}$.

observed in the $\mathrm{Mg}^{2+}$-alleviated plants than in the $\mathrm{Pb}^{2+}$-toxic plants (Figure 4B). These findings indicate that additional $\mathrm{Mg}^{2+}$ might increase the absorptive area of roots and, hence, increase the uptake of water and nutrients to improve plant growth
(Glinka, 1980). This finding was consistent with the observed ultrastructure of the $T$. grandis seedlings roots. The $\mathrm{Mg}^{2+}$ application protected the integrity of the root cells, resulting in a visible nucleus, slightly condensed chromatin and irregularly 
swollen mitochondria with fractured and fuzzy cristae (Figure 6). Thus, $\mathrm{Mg}^{2+}$ application is an effective method to alleviate $\mathrm{Pb}^{2+}$ toxicity in $T$. grandis seedlings by improving root growth and root oxidative activity and protecting root ultrastructure.

\section{CONCLUSION}

Torreya grandis seedlings exposed to $1400 \mathrm{mg} \mathrm{kg}^{-1} \mathrm{~Pb}^{2+}$ exhibited stress toxicity as indicated by reduced shoot growth. $\mathrm{Mg}^{2+}$ addition under $\mathrm{Pb}^{2+}$ stress conditions might have beneficial effects on the growth of $T$. grandis seedlings, as evidenced by increased shoot dry biomass, root dry biomass, chlorophyll contents, and photosynthesis as well as improved chloroplast ultrastructure. Moreover, additional $\mathrm{Mg}^{2+}$ in the solution containing $\mathrm{Pb}^{2+}$ decreased the $\mathrm{Pb}^{2+}$ concentration in the shoots and increased the $\mathrm{Mg}^{2+}$ concentration in the shoots. Furthermore, we showed that the positive effects of $\mathrm{Mg}^{2+}$

\section{REFERENCES}

Bose, J., Babourina, O., and Rengel, Z. (2011). Role of magnesium in alleviation of aluminium toxicity in plants. J. Exp. Bot. 62, 2251-2264. doi: 10.1093/jxb/ erq456

Buekers, J., Redeker, E. S., and Smolders, E. (2009). Lead toxicity to wildlife: derivation of a critical blood concentration for wildlife monitoring based on literature data. Sci. Total Environ. 407, 3431-3438. doi: 10.1016/j.scitotenv. 2009.01.044

Chen, G. J., Shi, H. B., Tao, J. S., Chen, L., Liu, Y. Y., Lei, G. L., et al. (2015). Industrial arsenic contamination causes catastrophic changes in freshwater ecosystems. Sci. Rep. 5:17419. doi: 10.1038/srep17419

Critchley, C. (1981). Studies on the mechanism of photoinhibition in higher plants: I. Effects of high light intensity on chloroplast activities in cucumber adapted to low light. Plant Physiol. 67, 1161-1165. doi: 10.1104/pp.67. 6.1161

Dai, Y., Shen, Z., Liu, Y., Wang, L., Hannaway, D., and Lu, H. (2009). Effects of shade treatments on the photosynthetic capacity, chlorophyll fluorescence, and chlorophyll content of Tetrastigma hemsleyanum Diels et Gilg. Environ. Exp. Bot. 65, 177-182. doi: 10.1016/j.envexpbot.2008.12.008

de Souza, S. C. R., de Andrade, S. A. L., de Souza, L. A., and Schiavinato, M. A. (2012). Lead tolerance and phytoremediation potential of Brazilian leguminous tree species at the seedling stage. J. Environ. Manage. 110, 299-307. doi: 10.1016/ j.jenvman.2012.06.015

Eide, D., Broderius, M., Fett, J., and Guerinot, M. L. (1996). A novel ironregulated metal transporter from plants identified by functional expression in yeast. Proc. Natl. Acad. Sci. U.S.A. 93, 5624-5628. doi: 10.1073/pnas.93.11. 5624

Glinka, Z. (1980). Abscisic acid promotes both volume flow and ion release to the xylem in sunflower roots. Plant Physiol. 65, 537-540. doi: 10.1104/pp.65. 3.537

Guerinot, M. L. (2000). The ZIP family of metal transporters. Biochim. Biophys. Acta 1465, 190-198. doi: 10.1016/S0005-2736(00) 00138-3

Gupta, D. K., Huang, H. G., Yang, X. E., Razafindrabe, B. H. N., and Inouhe, M. (2010). The detoxification of lead in Sedum alfredii $\mathrm{H}$. is not related to phytochelatins but the glutathione. J. Hazard. Mater. 177, 437-444. doi: 10. 1016/j.jhazmat.2009.12.052

Gupta, D. K., Nicoloso, F. T., Schetinger, M. R. C., Rossato, L. V., Pereira, L. B., Castro, G. Y., et al. (2009). Antioxidant defense mechanism in hydroponically grown Zea mays seedlings under moderate lead stress. J. Hazard. Mater. 172, 479-484. doi: 10.1016/j.jhazmat.2009.06.141

Hadi, F., Bano, A., and Fuller, M. P. (2010). The improved phytoextraction of lead $\left(\mathrm{Pb}^{2+}\right)$ and the growth of maize (Zea mays L.): the role of plant growth on the growth of $T$. grandis were triggered by protecting the morphology, activity and ultrastructure of the roots. To our knowledge, this study is the first study to show $\mathrm{Mg}^{2+}$-induced alleviation of lead toxicity in $T$. grandis seedlings and is of great importance for the cultivation of $T$. grandis seedlings in China, where soils are often contaminated with lead.

\section{AUTHOR CONTRIBUTIONS}

All authors listed, have made substantial, direct and intellectual contribution to the work, and approved it for publication.

\section{ACKNOWLEDGMENT}

This work was financially supported by the Special Fund for Forest Scientific Research in the Public Welfare (201504708).

regulators (GA3 and IAA) and EDTA alone and in combinations. Chemosphere 80, 457-462. doi: 10.1016/j.chemosphere.2010.04.020

Hermans, C., Chen, J., Coppens, F., Inzé, D., and Verbruggen, N. (2011). Low magnesium status in plants enhances tolerance to cadmium exposure. New Phytol. 192, 428-436. doi: 10.1111/j.1469-8137.2011.03814.x

Hu, J., Shi, G., Xu, Q., Wang, X., Yuan, Q., and Du, K. (2007). Effects of $\mathrm{Pb}^{2+}$ on the active oxygen-scavenging enzymes activities and ultrastructure in Potamogeton crispus leaves. Russ. J. Plant Physiol. 54, 414-419. doi: 10.1134/ S1021443707030181

Huang, G. P., Liu, Y. Q., and Cheng, L. (2006). Effect of $\mathrm{Pb}^{2+}$ pollution on physiological characteristics of Pinus rigida. Acta Agric. Univ. Jiangxiensis 28, $833-837$.

Huang, J. W., and Cunningham, S. D. (1996). Lead phytoextraction: species variation in lead uptake and translocation. New Phytol. 134, 75-84. doi: 10.1111/ j.1469-8137.1996.tb01147.x

Huang, Y., Wang, J., Li, G., Zheng, Z., and Su, W. (2001). Antitumor and antifungal activities in endophytic fungi isolated from pharmaceutical plants Taxus mairei, Cephalotaxus fortunei and Torreya grandis. FEMS Immunol. Med. Microbiol. 31, 163-167. doi: 10.1111/j.1574-695X.2001.tb00513.x

Hurlbert, S. H. (1984). Pseudoreplication and the design of ecological field experiments. Ecol. Monogr. 54, 187-211. doi: 10.2307/1942661

Kashem, M. D. A., and Kawai, S. (2007). Alleviation of cadmium phytotoxicity by magnesium in Japanese mustard spinach. Soil Sci. Plant Nutr. 53, 246-251. doi: 10.1111/j.1747-0765.2007.00129.x

Kaur, G., Kaur, S., Singh, H. P., Batish, D. R., Kohli, R. K., and Rishi, V. (2015). Biochemical adaptation in Zea mays root to short-term $\mathrm{Pb}^{2+}$ exposure: ROS generation and metabolism. Bull. Environ. Contam. Toxicol. 95, 246-253. doi: 10.1007/s00128-015-1564-y

Korshunova, Y. O., Eide, D., Clark, W. G., Guerinot, M. L., and Pakrasi, H. B. (1999). The IRT1 protein from Arabidopsis thaliana is a metal transporter with a broad substrate range. Plant Mol. Biol. 40, 37-44. doi: 10.1023/A: 1026438615520

Krabbenhoft, D. P., and Sunderland, E. M. (2013). Global change and mercury. Science 341, 1457-1458. doi: 10.1126/science.1242838

Krause, G. H., and Weis, E. (1991). Chlorophyll fluorescence and photosynthesis: the basics. Annu. Rev. Plant Biol. 42, 313-349. doi: 10.1146/annurev.pp.42. 060191.001525

Lamhamdi, M., Bakrim, A., Aarab, A., Lafont, R., and Sayah, F. (2011). Lead phytotoxicity on wheat (Triticum aestivum L.) seed germination and seedling growth. C. R. Biol. 334, 118-126. doi: 10.1016/j.ecoenv.2010. 08.041

Lichtenthaler, H. K. (1987). Chlorophylls and carotenoids - pigments of photosynthetic biomembranes. Methods Enzymol. 148, 350-382. doi: 10.1016/ 0076-6879(87)48036- 1 
Liu, D. H., Jiang, W., Liu, C., Xin, C., and Hou, W. (2000). Uptake and accumulation of lead by roots, hypocotyls and shoots of Indian mustard [Brassica juncea (L.)]. Bioresour. Technol. 71, 273-277. doi: 10.1016/S09608524(99)00082-6

Liu, R. X., Zhou, Z. G., Guo, W. Q., Chen, B. L., and Oosterhuis, D. M. (2008). Effects of $\mathrm{N}$ fertilization on root development and activity of water-stressed cotton (Gossypium hirsutum L.) plants. Agric. Water Manage. 95, 1261-1270. doi: 10.1016/S0960-8524(99)00082-6

Maherali, H., and DeLucia, E. H. (2000). Interactive effects of elevated CO2 and temperature on water transport in ponderosa pine. Am. J. Bot. 87, 243-249. doi: $10.2307 / 2656912$

Maxwell, K., and Johnson, G. N. (2000). Chlorophyll fluorescence a practical guide. J. Exp. Bot. 51, 659-668. doi: 10.1093/jexbot/51. 345.659

Mishra, A. (2012). Intermittent irrigation enhances morphological and physiological efficiency of rice plants. Agriculture 58, 121-130. doi: 10.2478/v10207-012-0013-8

Pittman, J. K. (2005). Managing the manganese: molecular mechanisms of manganese transport and homeostasis. New Phytol. 167, 733-742. doi: 10.1111/ j.1469-8137.2005.01453.x

Pourrut, B., Shahid, M., Dumat, C., Winterton, P., and Pinelli, E. (2011). Lead uptake, toxicity, and detoxification in plants. Rev. Environ. Contam. Toxicol. 213, 113-136. doi: 10.1007/978-1-4419-9860-6_4

Rashid, A., and Popovic, R. (1990). Protective role of $\mathrm{CaCl} 2$ against $\mathrm{Pb}^{2+}$ inhibition in photosystem II. FEBS Lett. 2711, 181-184. doi: 10.1016/0014-5793(90) 80401-4

Sharma, P., and Dubey, R. S. (2005). Lead toxicity in plants. Braz. J. Plant Physiol. 17, 35-52. doi: 10.1590/S1677-04202005000100004

Souza, J. F., Dolder, H., and Cortelazzo, A. L. (2005). Effect of excess cadmium and zinc ions on roots and shoots of maize seedlings. J. Plant Nutr. 28, 1923-1931. doi: $10.1080 / 01904160500310435$
Tang, H., Hu, Y. Y., Yu, W. W., Song, L. L., and Wu, J. S. (2015). Growth, photosynthetic and physiological responses of Torreya grandis seedlings to varies light environments. Trees 29, 1011-1022. doi: 10.1007/s00468-015$1180-9$

Thomine, S., Wang, R., Ward, J. M., Crawford, N. M., and Schroeder, J. I. (2000). Cadmium and iron transport by members of a plant metal transporter family in Arabidopsis with homology to Nramp genes. Proc. Natl. Acad. Sci. U.S.A. 97, 4991-4996. doi: 10.1073/pnas.97.9.4991

Wu, M., Wang, P. Y., Sun, L. G., Zhang, J. J., Yu, J., Wang, Y. W., et al. (2014). Alleviation of cadmium toxicity by cerium in rice seedlings is related to improved photosynthesis, elevated antioxidant enzymes and decreased oxidative stress. Plant Growth Regul. 74, 251-260. doi: 10.1007/s10725-0149916-x

Yang, M. G., Lin, X. Y., and Yang, X. E. (1998). Impact of Cd on growth and nutrient accumulation of different plant species. Chin. J. Appl. Ecol. 19, 89-94.

Zhang, J., Tian, S., Lu, L., Shohag, M. J. I., Liao, H., and Yang, X. (2011). Lead tolerance and cellular distribution in Elsholtzia splendens using synchrotron radiation micro-X-ray fluorescence. J. Hazard. Mater. 197, 264-271. doi: 10. 1016/j.jhazmat.2011.09.085

Conflict of Interest Statement: The authors declare that the research was conducted in the absence of any commercial or financial relationships that could be construed as a potential conflict of interest.

Copyright (๑ 2016 Shen, Song, Müller, Hu, Song, Yu, Wang and Wu. This is an open-access article distributed under the terms of the Creative Commons Attribution License (CC BY). The use, distribution or reproduction in other forums is permitted, provided the original author(s) or licensor are credited and that the original publication in this journal is cited, in accordance with accepted academic practice. No use, distribution or reproduction is permitted which does not comply with these terms. 